\title{
Melatonin Induces Cell Apoptosis in AGS Cells Through the Activation of JNK and P38 MAPK and the Suppression of Nuclear Factor-Kappa B: a Novel Therapeutic Implication for Gastric Cancer
}

\author{
Weimin Lia Mengdi Fan ${ }^{\mathrm{b}}$ Yina Chen ${ }^{\mathrm{a}}$ Qian Zhao Caiyun Song ${ }^{\mathrm{a}}$ Ye Yan ${ }^{\mathrm{a}}$ Yin Jin ${ }^{\mathrm{a}}$ \\ Zhiming Huang ${ }^{\mathrm{a}}$ Chunjing Lin ${ }^{\mathrm{a}}$ Jiansheng Wu${ }^{\mathrm{a}}$ \\ aDepartment of Gastroenterology, The First Affiliated Hospital of Wenzhou Medical University, \\ Wenzhou, 'Department of Endocrinology and Metabolism, The Second Affiliated Hospital of Wenzhou \\ Medical University, Wenzhou, China
}

\section{Key Words}

Melatonin • Apoptosis • Mitogen-activated protein kinases • Nuclear factor-kappa B

\begin{abstract}
Background/Aims: Melatonin, synthesized by the pineal gland and released into the blood, appears to have antitumour properties; however, the mechanisms of its anti-cancer effects are largely unknown, especially in stomach cancer. Here, we explore the antitumour activity of melatonin in a gastric cancer cell line (AGS) and analyse its molecular mechanisms. Methods: AGS cells were treated with melatonin, and cell viability was assessed using a CCK- 8 assay. Flow cytometry was performed to evaluate apoptosis, and protein expression was examined by Western blotting. Results: Melatonin significantly inhibited cell viability, clone formation, and cell migration and invasion and induced apoptosis in AGS cells. Moreover, MAPK pathways (p38, JNK and ERK) were activated by melatonin treatment, which also significantly increased caspase- 3 cleavage and Bax protein expression and decreased $\mathrm{Bcl}-2$ protein expression in a time-dependent manner. Our results demonstrate that p38 and JNK inhibitors (SB203580 and SP600125, respectively) prevented melatonin-induced apoptosis; thus, the propensity of p38 MAPK and JNK to promote apoptosis could be at least partly due to the inhibition of NF-KB p65 activation by p38 and JNK. Finally, melatonin was able to strengthen cisplatin-mediated antitumour effects in human gastric carcinoma cells by up-regulating the expression of Bax, down-regulating the expression of $\mathrm{Bcl}-2$ and activating the caspase-dependent apoptotic pathway. Conclusion: Melatonin induced apoptosis in AGS cells by activating the caspasedependent apoptotic pathway and by inhibiting the nuclear translocation of NF-kB p65, two processes that are regulated by p38 and JNK. Furthermore, melatonin significantly enhanced
\end{abstract}


the anti-tumour effects of cisplatin, with low systemic toxicity. These new findings suggest that melatonin may act as a potent anti-tumour agent and may have great potential as an adjuvant therapy in the future.

\section{Introduction}

Gastric cancer is one of the most common malignancies and is associated with a high mortality rate worldwide [1]. Asian patients tend to be diagnosed at an early age (66.8 years) and have extremely poor survival rates [2]. In general, conventional surgery and chemotherapy have improved overall survival, though not to a sufficient extent. Thus, identifying an efficient drug therapy for gastrointestinal tract cancer is an important focus of research, and more effective drugs or comprehensive therapies are required [3].

Melatonin (N-acetyl-5-methoxytryptamine), a pineal gland hormone, regulates sleep and circadian rhythm and also affects other important regulatory processes [4]. Indeed, melatonin plays significant roles in a wide variety of biological processes, including immunomodulation, anti-inflammation and oxidative stress responses [5-8]; some research has even shown that melatonin promotes cell survival in normal tissues [9-11] and that the antioxidant potential of melatonin may prevent cell death under both physiological and pathological conditions [12]. Melatonin also demonstrates oncostatic effects in different types of cancer [13-15]. Although the underlying molecular mechanism of the anti-cancer effects of melatonin in gastric cancer is largely unknown, various studies have reported that the anti-tumour capacity of melatonin may be mediated by several mechanisms, including the activation of anti-oxidation, the inhibition of migration and the induction of apoptosis in tumours [16-18]. A recent study reported that melatonin decreased B-cell lymphoma 2 (Bcl2 ) and increased Bcl-2-associated X (Bax) protein expression at both the mRNA and protein levels in murine foregastric carcinoma cells [16]. The pro-apoptotic effect of melatonin has also been shown in human gastric cancer cells (SGC7901) [19].

The mitogen-activated protein kinase (MAPK) pathway is a key signal transmission network in eukaryotes and plays important roles in cell survival and proliferation [20]. The MAPK family has been divided into three main groups: p38 MAPK, c-jun N-terminal kinase (JNK) and extracellular-regulated kinase 1/2 (ERK1/2) [21]. Recently, an increasing number of studies have demonstrated that p38 MAPK and JNK substrates are linked to cell growth and apoptosis [22], are implicated in cancer development and are affected by melatonin [23]. Tana et al. found that melatonin can suppress the transcription, translation and activity of MLCK through ERK1/2 signal transduction in the oesophageal epithelium of GERD patients [24].

Nuclear factor kappa B (NF-kB) belongs to the Rel family, which consists of p50, p52, c-Rel, RelA (p65) and RelB. As a transcription factor, NF- $\kappa B$ stimulates the expression of many genes related to oxidative stress, cytokine production and anti-apoptosis [25]. It has been reported that melatonin could suppress the NF- $\mathrm{BB}$ pathway in rat endothelial cells [26] and murine macrophages [27]. In addition, melatonin disturbs the synthesis of NO and the expression of the inducible isoform of nitric oxide synthase (iNOS) by suppressing the nuclear translocation of NF- $\kappa \mathrm{B}[26,27]$.

However, it is unknown whether melatonin influences apoptosis in human gastric cancer cells (e.g., AGS cells) via the p38, JNK and ERK signalling pathways. Thus, we investigated the effect of melatonin on the viability and apoptosis of AGS cells through MAPK pathways and examined whether melatonin induces apoptosis by decreasing the nuclear translocation of NF- $\kappa B$ via MAPK pathways. Because these pathways are at the junction of several signalling cascades, including those involved in various physiological and pathological processes, MAPK pathways may be associated with NF- $\kappa B$. Additionally, to assess the potential influence of melatonin on tumour chemotherapy, we also evaluated whether melatonin could enhance the anti-cancer effect of cisplatin in human gastric cancer cells. 


\section{Cellular Physiology Cell Physiol Biochem 2015;37:2323-2338 \begin{tabular}{l|l|l} 
and Biochemistry Published online: December 04, 2015 & $\begin{array}{l}\text { (c) } 2015 \text { The Author(s). Published by S. Karger AG, Basel } \\
\text { www.karger.com/cpb }\end{array}$
\end{tabular} \\ Li et al.: Melatonin Induces Apoptosis via JNK, P38 and NF-KB}

\section{Materials and Methods}

Cell culture and reagents

Human gastric cancer AGS cells were obtained from the Cell Bank of Type Culture Collection of Chinese Academy of Sciences (Shanghai, China), and human gastric mucosal cells (GES-1) were obtained from the American Type Culture Collection (Manassas, VA, USA). Samples of approximately $5 \times 10^{5}$ cells per flask were cultured in Roswell Park Memorial Institute-1640 medium (RPMI 1640; Sigma, St. Louis, MO, USA) supplemented with 10\% heat-inactivated foetal bovine serum (FBS; Sigma, St. Louis, MO, USA), $100 \mathrm{U} / \mathrm{ml}$ penicillin and $100 \mu \mathrm{l} / \mathrm{ml}$ streptomycin at $37^{\circ} \mathrm{C}$ with $5 \% \mathrm{CO}_{2}$ in a humidified incubator. The culture medium was renewed every 2 days. The cells were treated with different concentrations of melatonin at different times. Melatonin was purchased from Sigma (St. Louis, MO, USA), dissolved in dimethylsulfoxide (DMSO; Waltham, MA, USA) to different stock concentrations $(0.125,0.25,0.5,1$, and $2 \mathrm{M})$ and diluted with culture medium to $0.25,0.5,1,2$, and $4 \mathrm{mM}$ immediately before use. Thus, the cells were exposed to DMSO at $0.2 \%$; DMSO concentrations less than $1 \%$ have limited effects on cell behaviour [28].

Antibodies against phospho-p38 ((Thr180/Tyr182) rabbit mAb \#9215), p38 ((D13E1) rabbit mAb \#8690), phospho-Erk1/2 ((Thr202/Tyr204) rabbit mAb \#4370), Erk1/2 ((137F5) rabbit mAb \#4695), phospho-JNK ((Thr183/Tyr185) rabbit mAb \#4668), JNK (\#9252), phospho-NF-kB p65 ((Ser536) rabbit mAb \#3033), NF-кB p65 ((D14E12) rabbit mAb \#8242), caspase-3 (\#9662) and Bcl-2 ((D55G8) rabbit mAb \#4223) were purchased from Cell Signaling Technology (Beverly, MA, USA). Bax and GAPDH were purchased from Santa Cruz Biotechnology (Dallas, Texas, USA). The anti- $\beta$-Actin antibody was purchased from Abcam (Cambridge, MA, USA). Cisplatin was obtained from QiLu Pharmaceutical Corporation (Shandong, China).

\section{Colony-forming assays}

AGS cells were incubated in six-well plates $\left(5 \times 10^{5}\right.$ cells/well $)$ at $37^{\circ} \mathrm{C}$ in a humidified atmosphere containing $5 \% \mathrm{CO}_{2}$. On the following day, the cells were treated with 1 and $2 \mathrm{mM}$ melatonin for 8 days. Then, each well was washed twice with phosphate-buffered saline (PBS) and stained with Crystal Violet. During the 8-day incubation, the medium in all wells was changed every $48 \mathrm{~h}$.

\section{Cell viability assay}

The Cell Count Kit-8 (CCK-8; Dojindo, Japan) was used to assess the effect of melatonin on cell viability. For the CCK-8 assay, cells were seeded into 96-well culture plates $\left(4 \times 10^{3}\right.$ cell/well) in $200 \mu \mathrm{l}$ of complete medium; the plating medium was refreshed after $24 \mathrm{~h}$. Melatonin was dissolved in fresh medium at different doses $(0.5-4 \mathrm{mM})$; vehicle control cells were incubated in culture medium supplemented with $0.2 \%$ DMSO. Each group consisted of five parallel wells. After incubation for 12, 24, 48 and $72 \mathrm{~h}, \mathrm{CCK}-8$ was added to the culture media, and the supernatant of each well was measured at a wavelength of $450 \mathrm{~nm}$ using a plate reader (Infinite ${ }^{\circledR} 200$ PRO NanoQuant; Tecan Austria GmbH Untersbergstr, Austria). Each experiment was performed in triplicate. Cell viability in each group was calculated as the absorbance of the melatonintreated sample/cell control absorbance $\times 100$.

\section{Wound healing assay}

AGS cells were seeded in complete medium in 12 -well plates at a density of $3 \times 10^{4}$ cells/well at $37^{\circ} \mathrm{C}$ with $5 \% \mathrm{CO}_{2}$. When the cells formed a monolayer, a scratch was generated in the middle of the well with a 100- $\mu$ l pipette tip. Subsequently, the debris was removed, the plates were rinsed with PBS, and the cells were cultured with fresh media with different concentrations of melatonin $(0-2 \mathrm{mM})$ and $0.2 \%$ DMSO. After incubation for 0,24 and $48 \mathrm{~h}$, the cells were imaged using a phase-contrast microscope; each experiment was performed in triplicate. The initial migration of the scratch in the field of view was determined by the area divided by the length devoid of cells using Image-Pro Plus software (Media Cybernetics Co., Bethesda, MD). The results are expressed as the difference in migration distance between $0 \mathrm{~h}$ and $48 \mathrm{~h}$ of treatment.

\section{Invasion assay}

A cell migration assay was performed using 24 -well Transwell chambers with 8- $\mu$ m polycarbonate nucleopore filters, which were coated with $10 \mu \mathrm{g} /$ well Matrigel. Briefly, after treatment with $2 \mathrm{mM}$ melatonin, tumour cells were trypsinized and added to the upper Matrigel-coated chamber at a density of $3 \times 10^{4}$ cells/well in serum-free medium; 10\% FBS-containing medium was added to the lower chamber. 


\section{Cellular Physiology Cell Physiol Biochem 2015;37:2323-2338

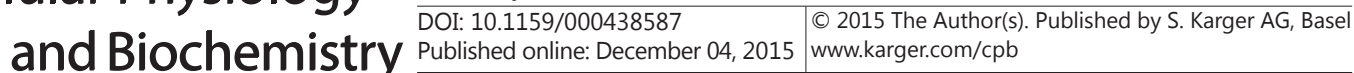 \\ Li et al.: Melatonin Induces Apoptosis via JNK, P38 and NF-KB}

After $24 \mathrm{~h}$, the cells that had invaded through the Matrigel and adhered to the bottom of the membrane were fixed with $4 \%$ paraformaldehyde for $15 \mathrm{~min}$ at room temperature and then stained with Crystal Violet for $20 \mathrm{~min}$. Next, the chambers were washed with PBS, and the upper surface of the membrane was wiped with a cotton swab to remove non-migratory cells. The cells on the lower surface were identified as invasive cells and were visualized using phase-contrast microscopy; the cells were counted using ImageJ software.

\section{Apoptosis assay using Annexin-V FITC/PI}

FITC-conjugated Annexin-V and propidium iodide (PI) (MultiSciences Biotech, Zhejiang, China) staining was used to detect the extent of early apoptosis and necrosis. Cells $\left(4 \times 10^{5}\right)$ were plated in 6-well plates and treated with $2 \mathrm{mM}$ melatonin for $0 \mathrm{~h}$ to $48 \mathrm{~h}$. The cells were harvested by trypsinization, washed with PBS, centrifuged at $1 \times 10^{3} \mathrm{rpm}$ for $5 \mathrm{~min}$ and resuspended in $1 \times$ binding buffer. Next, $500 \mu \mathrm{l}$ of each sample solution was added to $5 \mu \mathrm{l}$ of FITC-conjugated Annexin-V and $10 \mu \mathrm{l}$ of PI followed by incubation for $5 \mathrm{~min}$ in the dark at room temperature. The samples were subjected to flow cytometry using a fluorescenceactivated cell sorter and quantified using FlowJo software. Positioning of the quadrants on Annexin-V FITC/PI dot plots was used to distinguish among living cells (Annexin-V FITC-/PI'), early apoptotic cells (Annexin-V FITC ${ }^{+} / \mathrm{PI}^{-}$) and late apoptotic/secondary necrotic cells (Annexin-V FITC $/ \mathrm{PI}^{+}$) [23].

\section{Immunofluorescence assay}

To investigate the association between melatonin and NF- $\kappa$ B activation, NF- $\kappa$ B protein localization in AGS cells was investigated by an immunofluorescence assay. Cells $\left(4 \times 10^{5}\right)$ were incubated on coverslips in 6-well plates and treated with $2 \mathrm{mM}$ melatonin for $24 \mathrm{~h}$. The coverslips were washed three times with PBS and fixed with 4\% paraformaldehyde for $20 \mathrm{~min}$. The coverslips were washed with PBS to remove the paraformaldehyde, and 1\% Triton X-100 was added for 5 min to promote cell membrane permeability. After blocking with 1\% BSA, the cells were incubated with an anti-p65 antibody (Cell Signaling Technology, Beverly, MA, USA), and then an appropriate anti-rabbit secondary fluorescent antibody. Finally, the cells were stained with DAPI in the dark at room temperature. Images were captured using a Leica spectral confocal laser scanning microscope.

\section{Western blot analysis}

Cultured cells were homogenized in ice-cold RIPA buffer containing $50 \mathrm{mM}$ Tris-HCl, $150 \mathrm{mM} \mathrm{NaCl}$, $1 \%$ Triton X-100, $1 \%$ sodium deoxycholate, $0.1 \%$ SDS, sodium orthovanadate, sodium fluoride, EDTA, PMSF and PhosSTOP (Roche, Basel, Switzerland) for $30 \mathrm{~min}$ on ice. The cells were scraped off the plate, and the extracts were transferred to a microcentrifuge tube and centrifuged at $1.2 \times 10^{4} \mathrm{~g}$ for $20 \mathrm{~min}$. The protein concentration was determined by the BCA assay (Beyotime). Equal amounts of total protein $(40 \mu \mathrm{g})$ were separately subjected to 10-12\% SDS-PAGE and then transferred to PVDF membranes (Bio-Rad, Hercules, CA, USA) at $350 \mathrm{~mA}$ for $0.5-1 \mathrm{~h}$. The membranes were blocked at $25^{\circ} \mathrm{C}$ for $1 \mathrm{~h}$ in blocking buffer (TBS, $0.1 \%$ Tween-20, and 5\% non-fat dry milk) and then immunoblotted overnight at $4{ }^{\circ} \mathrm{C}$ with primary antibodies targeted against the following: phospho-p38, p38, phospho-ERK, ERK, phospho-JNK, JNK, phospho-p65, p65, Bcl-2, caspase-3, Bax and GAPDH (1:1000). After washing with TBS (pH 8.0) containing 0.1\% Tween-20, the membranes were incubated for $1 \mathrm{~h}$ at room temperature with goat anti-rabbit secondary IgG conjugated to horseradish peroxidase (HRP) (1:10,000; Bioworld Technology Inc, Minnesota, USA) and then washed with TBS containing $0.1 \%$ Tween-20. Finally, the protein bands were visualized using a Western Bright ECL detection kit (Advansta, Menlo Park, California, USA). The density of specific bands was quantified using Image Lab software (Bio-Rad, Hercules, California, USA) with an imaging densitometer (Bio-Rad ChemiDoc MP, Hercules, California, USA). The blots were also subjected to densitometry using GAPDH or $\beta$-actin as an internal control.

\section{Statistical analysis}

The results were analysed using SPSS software (v. 13) (Chicago, IL, USA). The data, which were expressed as percentages of the control, are reported as the means \pm S.E.M. Analysis of variance (ANOVA) was used for data comparisons; when the analysis showed the presence of a significant difference, the data were compared using the Newman-Keuls post-test. Statistical significance was accepted at $P<0.05$. 


\section{Results}

Effects of melatonin on AGS cell viability, colony formation, invasion, motility and apoptosis

We employed a human gastric cancer cell line (AGS) to assess the anti-cancer effects of melatonin on stomach carcinoma cells. The effect of melatonin on AGS cell viability was investigated using the CCK-8 assay, and cell viability was found to be significantly reduced by $1 \mathrm{mM}$ melatonin after $24 \mathrm{~h}$ of treatment ( $87 \%$ viability, Fig. 1A), with a maximum effect observed after $72 \mathrm{~h}$ using $4 \mathrm{mM}$ melatonin (5\% viability, Fig. 1A). A similar result was obtained when analysing the number of colonies formed, with significant decreases induced by melatonin treatment (1 $\mathrm{mM}$ and $2 \mathrm{mM}$ ) (Fig. 1B).

To evaluate the influence of melatonin on cell migration, cells were treated with varying concentrations of melatonin for various times. As shown in Fig. 2A, 2 mM melatonin dramatically reduced AGS cell migration (52\% of control at $48 \mathrm{~h}$ ). To further examine the inhibition of cell motility by melatonin, impacts on cell invasion interactions were investigated; the images shown in Fig. 2B illustrate the suppression of cell invasion in the treated cells compared with the control.

Annexin-V FITC/PI staining and flow cytometry, which allows for the identification of early apoptotic cells, were utilized to evaluate apoptosis in human gastric cancer cells after exposure to $2 \mathrm{mM}$ melatonin for $0 \mathrm{~h}$ to $48 \mathrm{~h}$. As shown in Fig. 3A, the percentage of early apoptotic cells after treatment for $24 \mathrm{~h}$ was approximately 19.7-fold of that for the control cells (Fig. 3A), and the early apoptotic rate (Annexin-V FITC positive, PI negative) was significantly increased after 24 to $48 \mathrm{~h}(25 \%$ at $24 \mathrm{~h}$ and $35 \%$ at $48 \mathrm{~h}$, Fig. 3B). These results indicated that melatonin had a pro-apoptotic effect on AGS cells.

\section{Effects of melatonin on the phosphorylation of MAPK pathway components}

Considering that treatment of AGS cells with melatonin inhibited cell viability and migration and induced apoptosis, the possible mechanisms were investigated by evaluating the effect on the elementary activation status of MAPKs. After treatment with $2 \mathrm{mM}$ melatonin, p38, JNK and ERK phosphorylation was significantly induced in a time-dependent manner (Fig. 4A); the levels of p38, JNK and ERK served as internal controls, with the phosphorylated

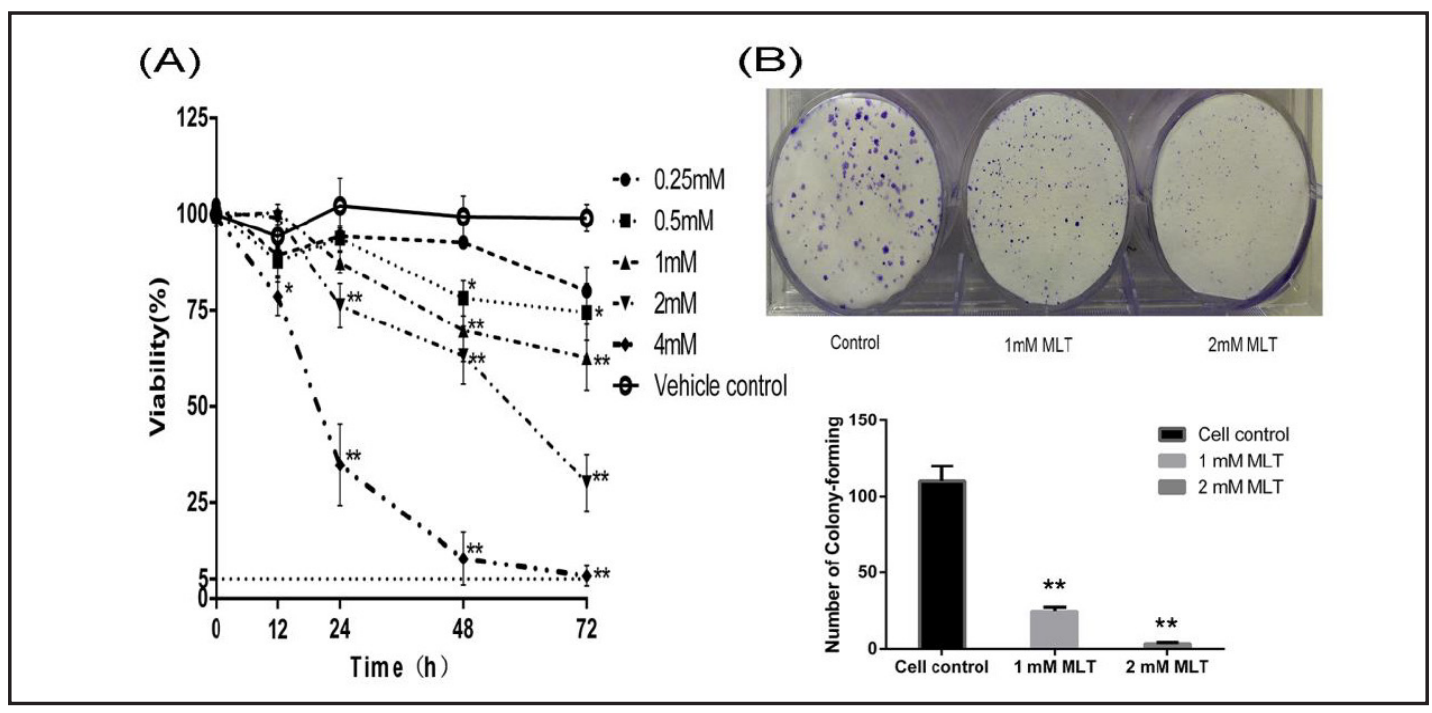

Fig. 1. Effects of melatonin on the viability and colony formation of AGS cells. (A) AGS cells were treated for $0,12,24,48$ or $72 \mathrm{~h}$ with various concentrations of melatonin $(0.25,0.5,1,2$ and $4 \mathrm{mM})$ or vehicle $(0.2 \%$ DMSO). Viability was assessed by the CCK-8 assay. (B) Cells were incubated in the absence (cell control) or presence of 1 and $2 \mathrm{mM}$ melatonin for 8 days; melatonin inhibits colony formation in AGS cells. The results are the means of three independent experiments. ${ }^{*} \mathrm{P}<0.05 ;{ }^{*} \mathrm{P}<0.01$ vs. control cells. MLT: melatonin. 


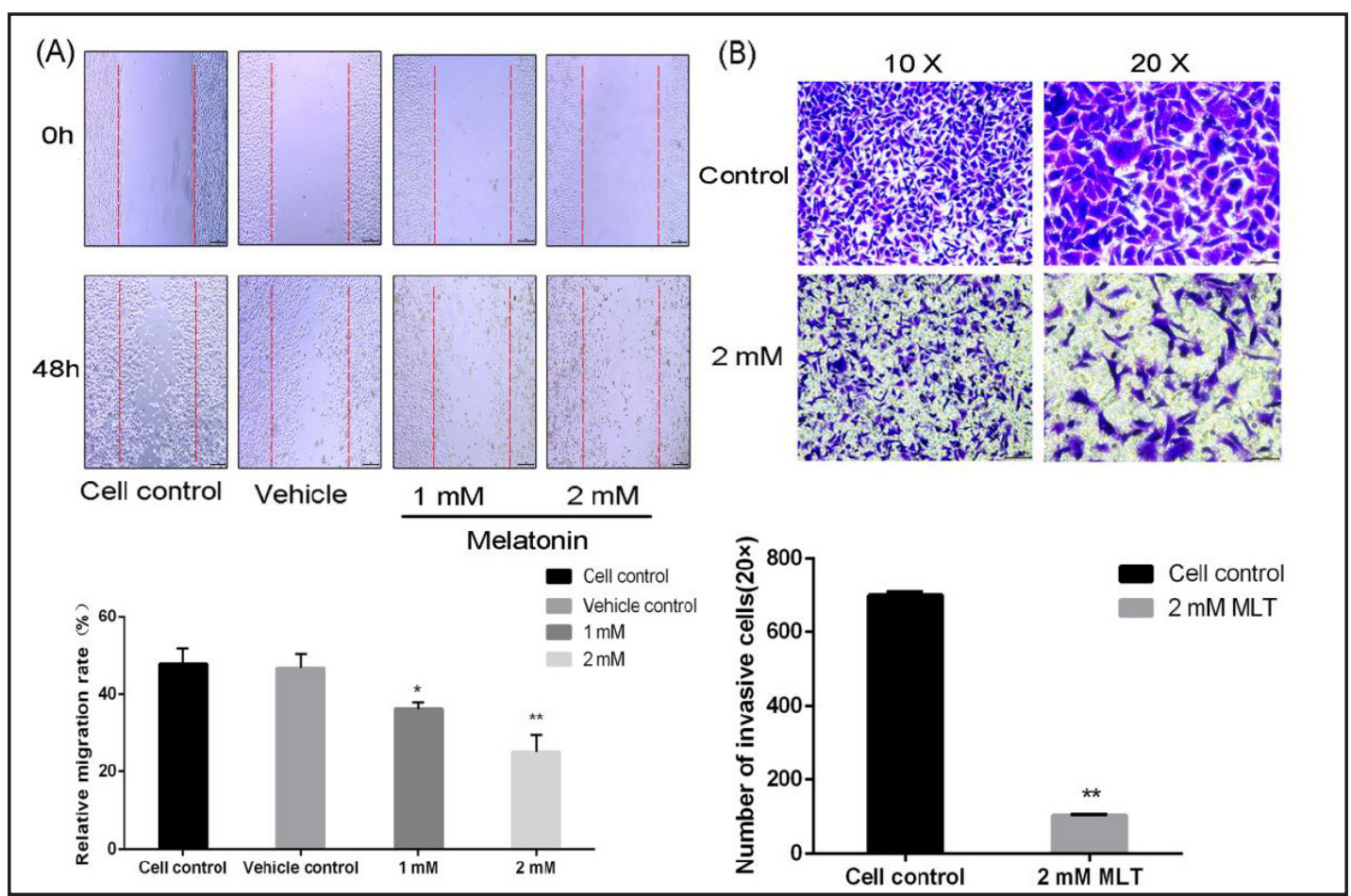

Fig. 2. Melatonin inhibits migration and invasion of AGS cells. (A) The migration of AGS cells treated with 0-2 mM melatonin or vehicle at different time points $(0,48 \mathrm{~h})$; analysis of the relative migration ratio at $48 \mathrm{~h}$ compared with the control group. (B) The invasion of AGS cells treated with $2 \mathrm{mM}$ melatonin for $24 \mathrm{~h}$ under $10 \times$ and $20 \times$ magnification. Representative images from three independent experiments are shown. ${ }^{*} \mathrm{P}<0.05 ;{ }^{* *} \mathrm{P}<0.01$ vs. control cells. MLT: melatonin.

Fig. 3. Melatonin induces apoptosis in AGS cells. (A) AGS cells were treated with $2 \mathrm{mM}$ melatonin for up to $48 \mathrm{~h}$. (B) The results are presented as the average early apoptotic rate from three randomized trials. Data represent the mean \pm S.E.M of three independent experiments. ${ }^{*} \mathrm{P}<0.05 ;{ }^{* *} \mathrm{P}<0.01$ vs. control cells $(0 \mathrm{~h})$.

protein level quantified considering $100 \%$ for the control (Fig. 4B). The results revealed clear increases in p-p38, p-JNK and p-ERK activity at 24 $\mathrm{h}$ and $48 \mathrm{~h}$.

Effect of melatonin on AGS cell pro-apoptosis and protease secretion via p38 and JNK signalling

To determine whether the induction of Bax and caspase- 3 and the inhibition of $\mathrm{Bcl}-2$ secretion by melatonin occur mainly through p38MAPK and JNK pathway activation, we investigated the effects of specific

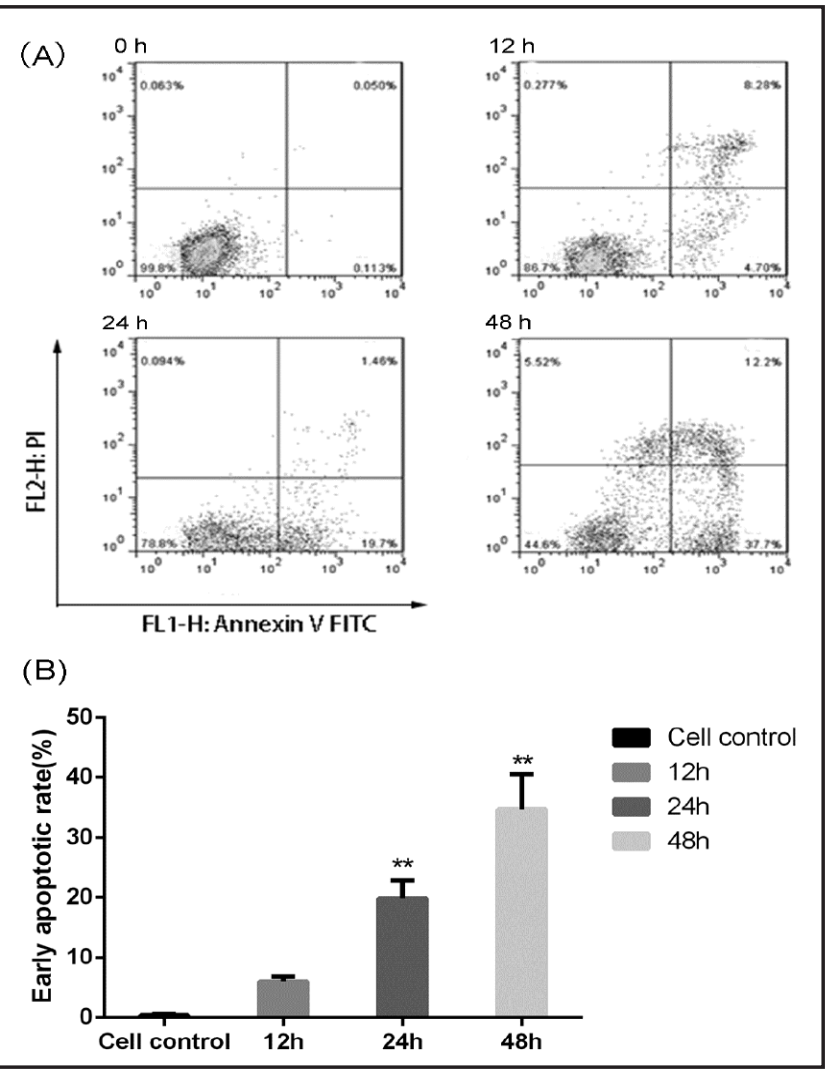




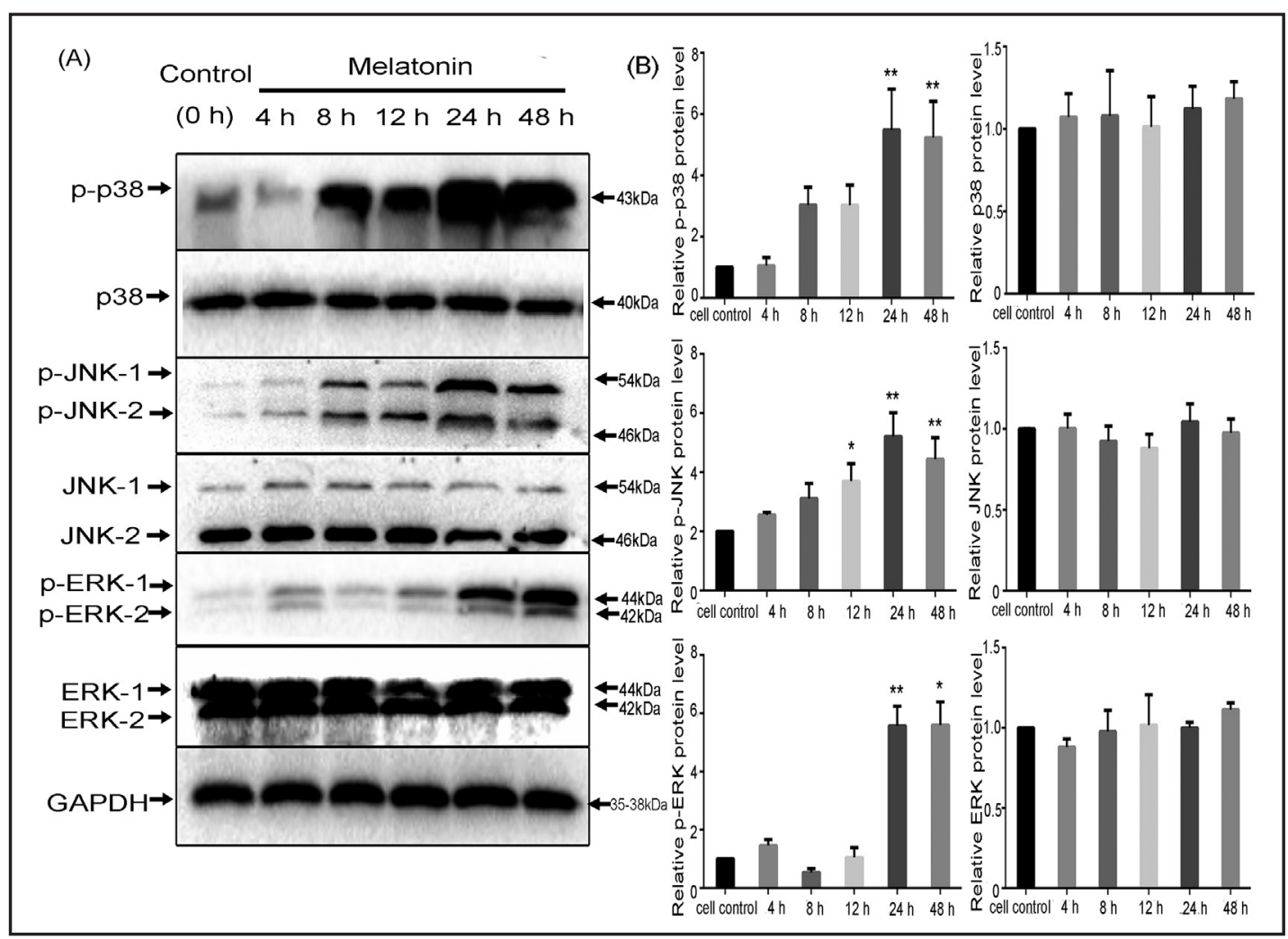

Fig. 4. Effects of melatonin on the phosphorylation of MAPK pathway components. (A) AGS cells were treated with $2 \mathrm{mM}$ melatonin for $0 \mathrm{~h}$ to $48 \mathrm{~h}$, and cell lysates were subjected to SDS-PAGE followed by Western blotting with anti-phospho-p38, anti-p38, anti-phospho-JNK, anti-JNK, anti-phospho-ERK and anti-ERK antibodies. Signals of proteins were visualized with an ECL detection system. (B) The levels of ERK, p38 and JNK were used as internal controls; the phosphorylated proteins were quantified by densitometric analysis with using the control as $100 \%$. Data represent the mean \pm S.E.M of at least three independent experiments. ${ }^{*} \mathrm{P}<0.05$; ${ }^{* *} \mathrm{P}<0.01$ vs. control cells. p-p38: phospho-p38, p-JNK: phospho-JNK, p-ERK: phospho-ERK.

p38-MAPK inhibitor (SB203580), ERK inhibitor (PD98059) and JNK inhibitor (SP600125) on AGS cells treated with melatonin (Fig. 5). Bax up-regulation and Bcl-2 down-regulation were detected in the melatonin + PD98059-treated cells, suggesting that the ERK signalling pathway is not related to melatonin-induced apoptosis. In contrast, the SB203580-treated and SP600125-treated cells demonstrated inhibition, showing that both p38 and JNK are likely involved in the apoptosis induced by melatonin. Moreover, treatment with SB203580 or SP600125 led to inhibition of caspase-3 activity, which induces profound apoptosis. When treated with p38 and JNK inhibitors, cells exposed to melatonin showed significant suppression of caspase-3 activation. Therefore, melatonin most likely increases Bax expression and decreases Bcl-2 expression, resulting in increased cleaved-caspase- 3 via p38 and JNK. However, inhibition of ERK signalling pathways was not associated with Bax, Bcl-2 or caspase-3 activity.

Melatonin inhibits NF- $\kappa B$ activation via $p 38$ and JNK pathways

To examine whether the inhibitory effect of melatonin on NF- $\kappa \mathrm{B}$ expression is linked to the p38, JNK and ERK signalling pathways, the total protein level of NF- $\mathrm{KB}$ was analysed by Western blotting. First, to determine whether melatonin is involved in the inhibition of $\mathrm{NF}-\kappa \mathrm{B}$, we examined the kinetic profile of p65 activation upon melatonin stimulation using phospho-p65 and total p65 antibodies. The results of Western blot analysis demonstrated that melatonin $(2 \mathrm{mM}$ ) resulted in a marked decrease in phospho-p65 from $8 \mathrm{~h}$ to $48 \mathrm{~h}$ (Fig. $6 \mathrm{~A}$ and $\mathrm{B})$. In addition, alterations in the levels of $\mathrm{p} 65$ with respect to the melatonin dose were 


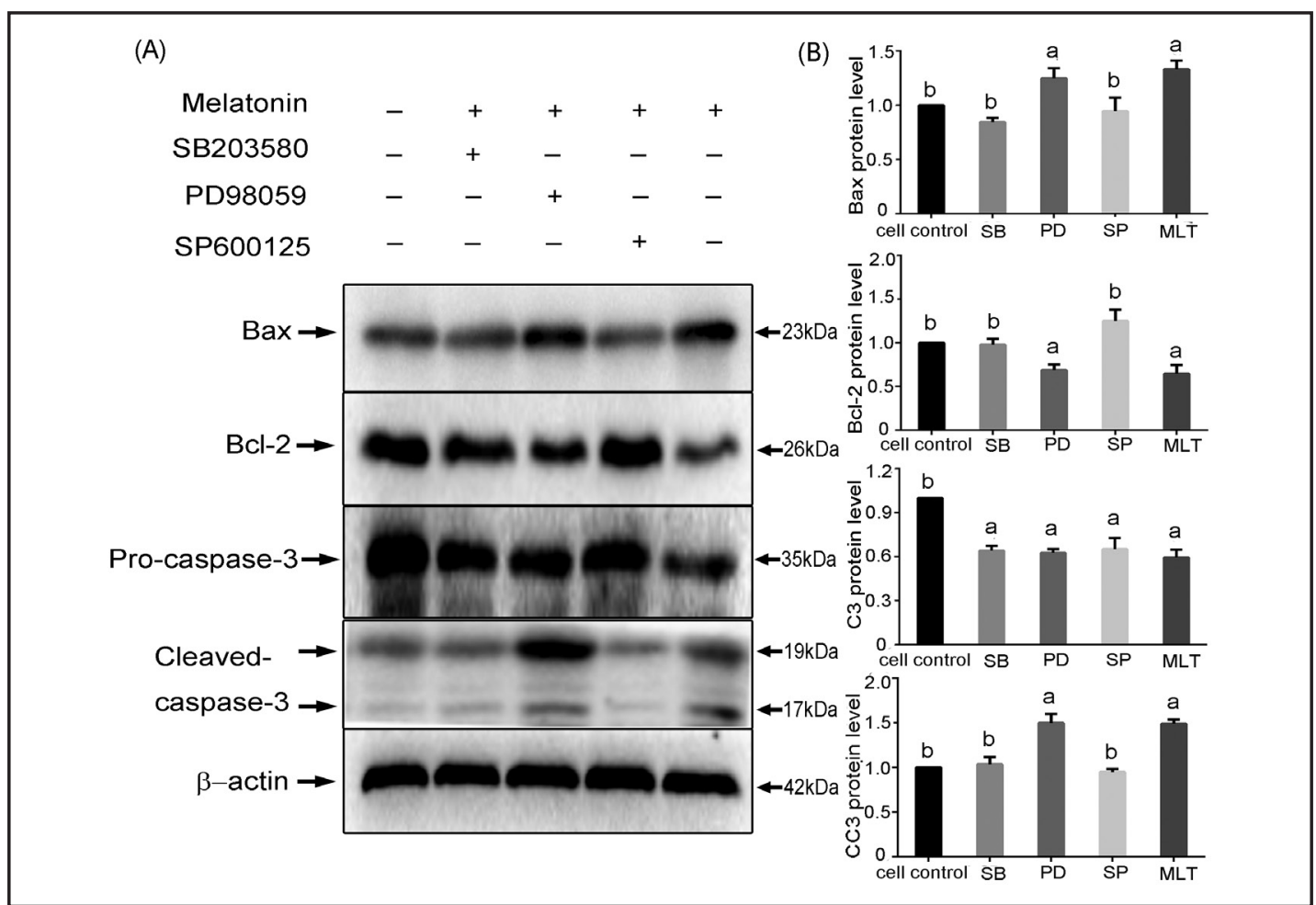

Fig. 5. Effects of melatonin, a p38 MAPK inhibitor (SB203580), an ERK inhibitor (PD98059), and a JNK inhibitor (SP600125) on the activities of Bax, Bcl-2, pro-caspase-3 and cleaved-caspase-3. (A) Cells were pre-treated with SB203580 (30 $\mu \mathrm{M})$, PD98059 (30 $\mu \mathrm{M})$ or SP600125 (30 $\mu \mathrm{M})$ for 60 min and then incubated with or without melatonin ( $2 \mathrm{mM}$ ) for $24 \mathrm{~h}$. Protein levels of Bax, Bcl-2, pro-caspase-3 and cleaved-caspase-3 were determined by Western blotting analysis. (B) The levels of Bax, Bcl-2, pro-caspase-3 and cleavedcaspase- 3 proteins were quantified by densitometric analysis using the control as $100 \%$, as shown just below the blot data. Data represent the mean \pm S.E.M of at least three independent experiments. ${ }^{\text {a }}<0.05$, vs. control cells, ${ }^{\text {b }}<0.05$ vs. melatonin alone, C3: pro-caspase-3, CC3: cleaved-caspase-3, SB: SB203580, PD: PD98059, SP: SP600125, MLT: melatonin.

similar to changes in localization (Fig. 6C): melatonin-stimulated cells revealed extensive and clear cytoplasmic staining for p65, indicating inhibition of the nuclear translocation of activated phosphorylated-p65.

To further confirm that MAPK is an intermediate in the pathway that links responses to melatonin to NF- $\mathrm{kB}$ inhibition, endogenous p38, JNK and ERK expression was silenced in AGS cells by pretreatment with SB203580 $(30 \mu \mathrm{M})$, SP600125 $(30 \mu \mathrm{M})$, and PD98059 $(30 \mu \mathrm{M})$, respectively, followed by the addition of melatonin for $24 \mathrm{~h}$. The inhibition of p38 and JNK resulted in increasing melatonin-mediated NF- $\kappa B$ nuclear translocation compared with cells stimulated by melatonin only (Fig. 6D). However, the changes in NF- $\kappa B$ due to PD98059 treatment were consistent with alone melatonin group. Taken together, the results of Western blot analysis of NF- $\kappa$ B revealed that $\mathrm{p} 38$ MAPK and JNK may be critical mediators of melatonin-suppressed NF- $\mathrm{B}$ expression in AGS cells, whereas ERK is not.

Melatonin enhances the effectiveness of cisplatin by suppressing AGS cancer cells

Melatonin affects AGS cell viability, as AGS cells exposed to increasing concentrations of melatonin exhibited reduced viability to different degrees. No significant toxicity was observed in human gastric mucosal GES- 1 cells treated with melatonin at concentrations of $3 \mathrm{mM}$ or less (Table 1). Therefore, $2 \mathrm{mM}$ melatonin was selected as the physiological concentration for the experiments. In this study, an average AGS cell viability of $60 \%$ was detected by CCK8 with $4 \mu \mathrm{g} / \mathrm{ml}$ cisplatin treatment. However, when cisplatin $(4 \mu \mathrm{g} / \mathrm{ml})$ was combined with 


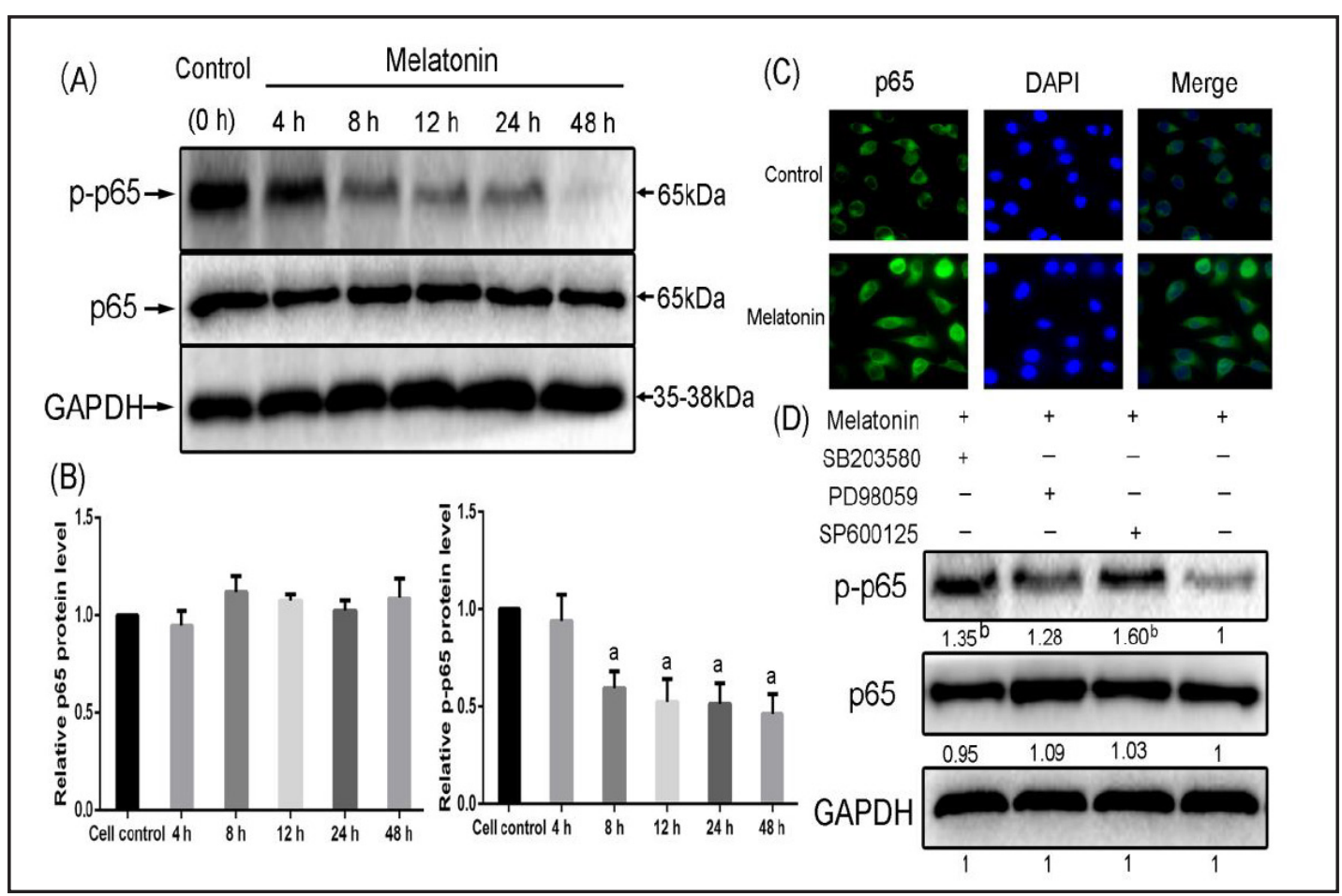

Fig. 6. Inhibitory effects of melatonin on NF- $\mathrm{\kappa B}$ and inhibitory effects of SB203580, PD98059 and SP600125 on the activities of NF- $\kappa$ B. (A) Cells were treated with melatonin at concentrations of $2 \mathrm{mM}$ for $0 \mathrm{~h}$ to 24 $\mathrm{h}$, and cell lysates were subjected to SDS-PAGE followed by Western blotting with anti-phospho-p65 and anti-p65 antibodies. (B) The levels of p-p65 and p65 proteins were quantified by densitometric analysis using the control as $100 \%$, as shown just below the blot data. (C) Altered nuclear translocation of NF$\kappa \mathrm{B}$ in AGS cells following $2 \mathrm{mM}$ melatonin treatment for $24 \mathrm{~h}$. After cell fixation, nuclei were visualized by blue DAPI staining, and nuclear NF- $\mathrm{B}$ translocation was monitored by overlay with anti-p65 green immunofluorescence microscopy. (D) Cells were pre-treated with SB203580 (30 $\mu \mathrm{M})$, PD98059 (30 $\mu \mathrm{M})$ or SP600125 (30 $\mu \mathrm{M})$ for $60 \mathrm{~min}$ and then incubated with melatonin $(2 \mathrm{mM})$ for 24 h. Protein levels of p65 and p-p65 were determined by Western blotting analysis. Data represent the mean \pm S.E.M of at least three independent experiments. ${ }^{\mathrm{P}}<0.05$, vs. control cells, ${ }^{\mathrm{b}} \mathrm{P}<0.05$ vs. melatonin alone, p-p65: phospho-p65.

melatonin ( $2 \mathrm{mM}$ ), AGS cell viability was reduced to $47 \%$ (Fig. 7). This result indicated that cisplatin or melatonin reduces AGS cell viability and that the inhibitory effect is significantly increased by the combined treatment.

In a subsequent set of experiments, we examined whether the combination treatment-mediated anti-tumour effect was mediated by apoptosis. To this end, AGS cells were treated with $2 \mathrm{mM}$ melatonin, $4 \mu \mathrm{g} / \mathrm{ml}$ cisplatin or both melatonin and cisplatin for 24 $\mathrm{h}$, and apoptosis-related protein expression was detected by Western blotting using antibodies against $\mathrm{Bax}, \mathrm{Bcl}-2$, pro-caspase- 3 and cleaved-caspase-3. Melatonin in combination with cisplatin resulted in significantly increased levels of Bax and cleaved-caspase-3 and
Table 1. Effect of melatonin and cisplatin on cell viability of AGS and GES- 1 cells. ${ }^{a} P<0.05$, vs. Cell control; ${ }^{b} P<0.05, \mathrm{vs} .4 \mu \mathrm{g} / \mathrm{ml}$ CDDP alone. CDDP:cisplatin; MLT:melatonin

\begin{tabular}{cccc}
\hline AGS cells & Viability $(\%)$ & GES-1 cells & Viability $(\%)$ \\
\hline CDDP $(\mu \mathrm{g} / \mathrm{ml})$ & \multicolumn{3}{c}{ CDDP $(\mu \mathrm{g} / \mathrm{ml})$} \\
2 & $67.8^{\mathrm{a}}$ & 2 & $50.9^{\mathrm{a}}$ \\
4 & $59.9^{\mathrm{a}}$ & 4 & $28.7^{\mathrm{a}}$ \\
6 & $44.2^{\mathrm{a}}$ & 6 & $5.1^{\mathrm{a}}$ \\
$\mathrm{MLT}(\mathrm{mmol} / \mathrm{L})$ & & $\mathrm{MLT}(\mathrm{mmol} / \mathrm{L})$ \\
1 & $87.3^{\mathrm{a}}$ & 1 & 103.8 \\
2 & $75.6^{\mathrm{a}}$ & 2 & 92.2 \\
3 & $39.8^{\mathrm{a}}$ & 3 & 81.8 \\
$\mathrm{CDDP}(\mu \mathrm{g} / \mathrm{ml})+\mathrm{MLT}(\mathrm{mmol} / \mathrm{L})$ & $\mathrm{CDDP}(\mu \mathrm{g} / \mathrm{ml})+\mathrm{MLT}(\mathrm{mmol} / \mathrm{L})$ \\
$4+2$ & $47.0^{\mathrm{a} b}$ & $4+2$ & $30.8^{\mathrm{a}}$ \\
$4+3$ & $22.2^{\mathrm{ab}}$ & $4+3$ & $28.5^{\mathrm{a}}$ \\
\hline
\end{tabular}


(A)

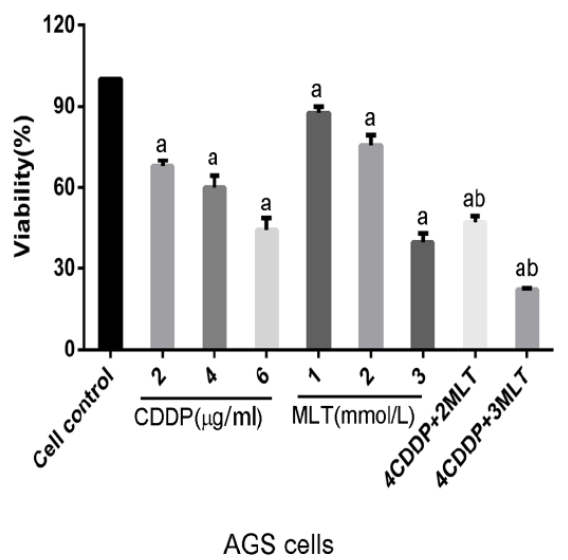

(B)

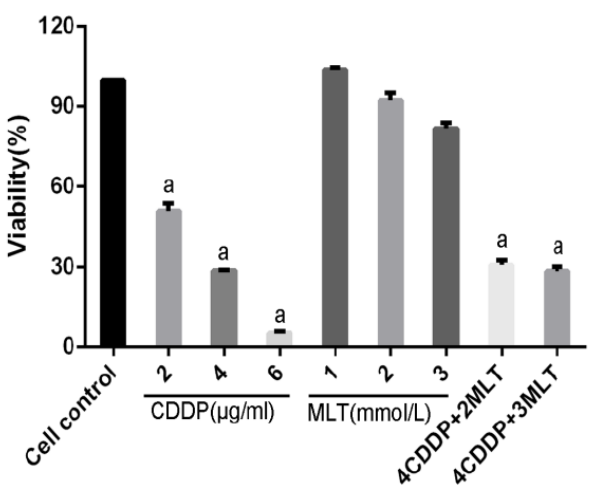

GES-1 cells

Fig. 7. Effects of melatonin and cisplatin on the viability of AGS and GES-1 cells. (A) AGS cells were treated for $24 \mathrm{~h}$ with various concentrations of cisplatin $(2,4$ and $6 \mu \mathrm{g} / \mathrm{ml})$, melatonin $(1,2$ and $4 \mathrm{mmol} / \mathrm{L})$ or their combination $(4 \mu \mathrm{g} / \mathrm{ml}$ cisplatin $+2 \mathrm{mmol} / \mathrm{L}$ melatonin and $4 \mu \mathrm{g} / \mathrm{ml}$ cisplatin $+3 \mathrm{mmol} / \mathrm{L} \mathrm{melatonin)}$. Viability was assessed by the CCK-8 assay. (B) GES-1 cells were incubated under the same conditions, and cell viability was assessed. The results are the means of three independent experiments. ${ }^{a} \mathrm{P}<0.05$ vs. control cells; ${ }^{\text {bP }}<0.05$ vs. $4 \mu \mathrm{g} / \mathrm{ml}$ CDDP alone; CDDP: cisplatin; MLT: melatonin.

Fig. 8. Effects of combination treatment on the expression of apoptosis proteins in AGS cells. (A) Representative Western blot showing the expression of $\mathrm{Bax}, \mathrm{Bcl}-2$, pro-caspase-3, and cleaved-caspase-3 in AGS cells after treatment with melatonin $(2 \mathrm{mM})$, cisplatin $(4 \mu \mathrm{g} / \mathrm{ml})$ or their combination for 24 h. (B) The levels of Bcl-2/ Bax and cleaved-caspase-3 proteins were quantified by densitometric analysis using the control as $100 \%$, as shown just below the blot data.

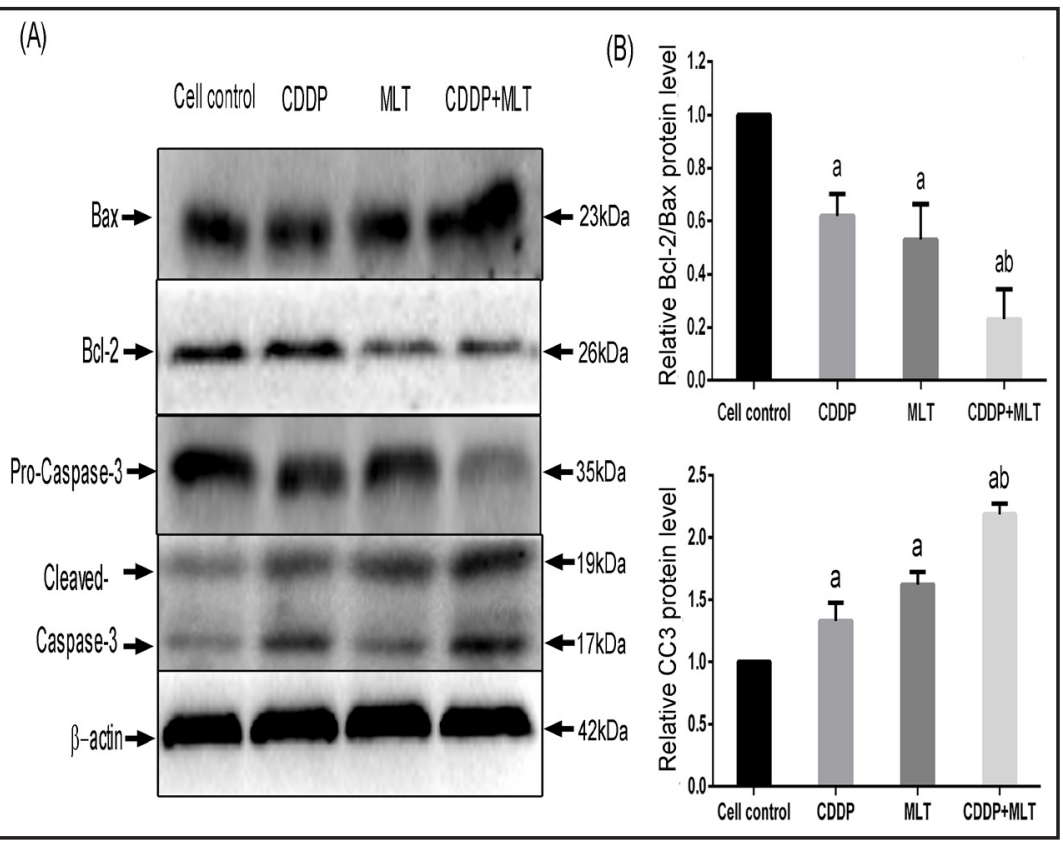
CDDP: cisplatin, MLT: melatonin. ${ }^{a} \mathrm{P}<0.05$ vs. control cells; ${ }^{\mathrm{b}} \mathrm{P}<0.05$ vs. CDDP alone. CC3: cleaved-caspase- 3 .

decreased levels of Bcl-2 and pro-caspase-3 compared with untreated cells or those treated with melatonin or cisplatin alone (Fig. 8).

\section{Discussion}

Gastric cancer is one of the leading causes of cancer mortality worldwide, and the incidence can increase dramatically based on gender or ethnicity [29]. Drug therapy is a 


\section{Cellular Physiology Cell Physiol Biochem 2015;37:2323-2338

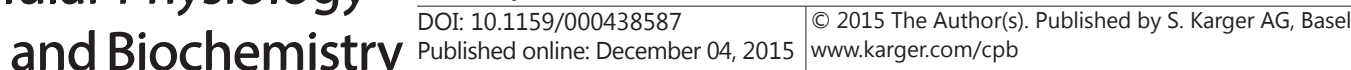 \\ Li et al.: Melatonin Induces Apoptosis via JNK, P38 and NF-KB}

promising strategy to halt the development of such tumours. Indeed, modern therapies provide effective ways to treat cancer but demonstrate certain toxicity and side effects, such as chemotherapy-induced peripheral neurotoxicity [30], endocrine therapy-induced menopause-like syndrome [31], or radiation-induced stomatitis [32]. However, melatonin could be effective in this field as a natural supplementary medicine. Although its therapeutic role has been studied by many investigators, the underlying mechanisms of its effects are poorly understood. Apoptosis, one of the potential mechanisms of anti-tumour activity, is a fundamental process in the development of various cell types. Thus, we investigated the induction of apoptosis by melatonin in gastric cancer cells.

In the current study, we demonstrated that melatonin inhibited AGS cell viability, migration and invasion in a dose- and time-dependent manner (Fig. 1, 2). Furthermore, melatonin was shown to induce apoptosis at suitable concentrations. Pro-apoptosis is considered to be the most appropriate method of cancer treatment, and Joo et al. reported that apoptosis is characterized by the activation of caspases related to cell viability [23]. Many previous studies have demonstrated that ERK pathway stimulation affects a survival signal that suppresses pro-apoptotic effects by activating p38 and JNK [33, 34]. Cisplatin induces apoptotic death and arrests cell growth through ERK activation [35], and paclitaxel, a potent inducer of G2/M cell cycle arrest and apoptosis, requires the activation of MAPK pathways (ERK and p38) [36].

Therefore, we determined whether melatonin induces apoptosis via MAPK (p38, JNK and ERK) signal transduction pathways in AGS cells. Our goal was to identify the underlying mechanism of the effect of melatonin as a potential apoptosis inducer. As shown by our Western blot analysis of MAPKs, p38, JNK and ERK phosphorylation was remarkably enhanced by melatonin at $24 \mathrm{~h}$ and $48 \mathrm{~h}$ (Fig. 4). Furthermore, induction of the mitochondriamediated pathway of apoptosis by melatonin was indicated by increases in pro-apoptotic Bax and decreases in anti-apoptotic Bcl-2. These findings suggest that melatonin enhances the translocation of Bax protein to the mitochondria, permeabilization of the mitochondrial membrane and stimulation of caspase activity. Our results demonstrated that Bax and Bcl2 expression was unchanged by PD98059 compared with melatonin alone, whereas the SP600125- and SB202190-treated cells exhibited increased Bax and decreased Bcl-2. These findings are in agreement with our previous hypothesis that melatonin induces apoptosis via the JNK and p38 signalling pathways, independently of ERK signalling. Moreover, the results showed that caspase-3 expression was responsive to SP600125 and SB202190 treatment, findings that are consistent with the results for Bax and Bcl-2 expression. Thus, a signalling molecule in apoptosis was activated by melatonin via p38 and JNK and promoted an increase in the Bax protein level, whereas the Bcl-2 cell survival protein level was decreased in the cytoplasm. Both Bax and Bcl-2 regulate caspase- 3 activity. These findings are consistent with those of a previous report [23]. Recent studies have suggested a key role for p38 MAPK and JNK in mediating pathways leading to apoptosis and growth-inhibitory signals $[37,38]$. Additionally, p38 MAPK and JNK trigger caspase-3 activation and are also necessary for the phosphorylation of apoptosis-related proteins, including Bax and Bcl-2, in cancer cells [23, 39]. Given these results, we speculate that melatonin promotes gastric cancer apoptosis by activating p38 and JNK, which trigger the overexpression of caspase-3. In contrast, PD98059 did not inhibit caspase-3 activity in AGS cells, revealing that melatonin-induced phosphoERK may not be correlated with melatonin-mediated apoptosis.

The transcription factor NF- $\mathrm{KB}$ family comprises closely related protein dimers that bind to a common DNA sequence motif called the $\kappa B$ site [40]. Upon activation, NF- $\kappa B$ p65 is released from the IKB complex and translocates to the nucleus, where it induces the expression of genes encoding various proteins involved in suppressing apoptosis and inducing cellular proliferation, invasion and inflammation [41]. These target genes are important for the development of invasive tumours and include those encoding cell-cycle regulatory proteins, such as cyclin D1, and apoptosis-suppressor proteins, such as Bcl-2 and Bcl-XL [42]. Exceptional NF- $\kappa$ B activation is associated with the stimulation of proliferation and protection against apoptosis in malignant cells [43]. Many dietary phytochemicals have 
been shown to suppress NF- $\kappa B$, including curcumin [44], guggulsterone [45] and flavopiridol [46]. Here, we provide evidence that melatonin may inhibit the phosphorylation of NF- $\kappa B$ p65 (Fig. 6A and B). However, we cannot rule out the possibility that the observed effects of melatonin on the activation of signalling pathways could lead to NF- $\kappa \mathrm{B}$ activation under short-term treatment and that the desensitization of those cascades could occur under longterm treatment ( $48 \mathrm{~h}$ ), with those effects possibly contributing to the subsequent downregulation of NF- $\mathrm{BB}-\mathrm{p} 65$ phosphorylation. The latter raises the possibility that p38 MAPK and JNK activation by melatonin may be important for some of the pro-apoptotic activities of melatonin, including its inhibition of p65 phosphorylation. The present study provides evidence that p38 MAPK and JNK activation possibly inhibits the phosphorylation of p65 based on the observation that treatment with MAPK inhibitors (SB203580 and SP600125) prevented the ability of melatonin to suppress the phosphorylation of p65 (Fig. 6D). To determine whether the ERK pathway is also involved in the inhibition of p65 phosphorylation by melatonin, we examined the ERK kinase pathway, as well as p38 and JNK activity. In fact, under the same conditions, the ERK pathway did not inhibit the release of activated NF- $\kappa \mathrm{B}$, a result that contrasts with data showing that the phosphorylation of ERK1/2 regulates the phosphorylation (and activation) of NF- $\mathrm{B}$ [47]. Indeed, an ERK inhibitor attenuated the forcemediated stimulation of NF- $\kappa B$ DNA binding in human periodontal ligament fibroblasts but not in the presence of a JNK or p38 MAPK inhibitor [48]. In addition, accumulating evidence indicates that the ERK1/2 inhibitor U0126 can suppress the IL-20-induced activation of IKK, the phosphorylation and degradation of $I \kappa B \alpha$, and the translocation of p65 subunits in bladder cancer cells [49]. It is interesting to note that the JNK/ NF- $\mathrm{KB}$ cascade has been shown to participate in acetaldehyde-induced MMP-9 expression in hepatocellular cancer cells [50]. Moreover, Kim et al. found that reactive oxygen species activate CK2 via p38, which, in turn, induces NF- $\kappa B$ activation [51]. This information indicates that different MAPK family members are differentially involved in NF- $\kappa \mathrm{B}$ activation under various stimulants and in different cell types [52].

There is evidence that both p38 MAPK and JNK activation promote cell apoptosis in tumour cells under some circumstances [53-55]. There is also extensive evidence showing that NF- $\kappa B$ activation suppresses apoptosis, most likely because NF- $\kappa B$ promotes the synthesis of proteins that can protect cells from apoptosis [56-59]. Our findings suggest that the tendency of p38 MAPK and JNK to promote apoptosis could be at least partly due to the inhibition of NF- $\mathrm{KB}$ activation by p38 and JNK. However, other factors are likely to be involved in these processes because incubating cells in the presence of the p38 kinase inhibitor SB203580 could not confer significant protection from melatonin-induced apoptosis [60, 61].

Based on our studies, we conclude that melatonin is a potent suppressor of cell viability and an inducer of apoptosis in gastric cancer cell lines. These results may be associated with promotion of the p38 MAPK and JNK machinery but not the ERK pathway. Indeed, p38 and JNK inhibitors prevented the ability of melatonin to suppress the phosphorylation of p65. These results suggest that p38 MAPK and JNK not only promote cell apoptosis via the mitochondria-mediated pathway of apoptosis (Bax and Bcl-2) but also inhibit protection against apoptosis (NF- $\mathrm{KB}$ ). However, Bain et al. have recommend that using SP600125 as a JNK inhibitor should be discontinued in cell-based assays because of the lack of specificity of the compound [62]. Based on this shortcoming, our plan in further experiments is to inhibit protein expression via gene silencing, thereby enhancing the validity and reliability of our results.

Anticancer activity does not necessarily indicate changes in only cell proliferation or cell migration. Our data showed that melatonin could activate the ERK pathway in gastric cancer cells within the treatment times examined. A study that investigated the anticancer effect of paclitaxel demonstrated that ERK activation is associated with cell cycle arrest in G2/M phase [63]. Pro-death autophagy is the most recent anti-tumour activity to be described as a prosurvival mechanism, and studies have suggested that autophagy can promote cell death within different cellular contexts. Ordonez et al. reported that melatonin induced autophagy 


\section{Cellular Physiology Cell Physiol Biochem 2015;37:2323-2338 \begin{tabular}{l|l|l}
\hline DOI: 10.1159/000438587 & $\begin{array}{l}\text { C) } 2015 \text { The Author(s). Published by S. Karger AG, Basel } \\
\text { www.karger.com/cpb }\end{array}$ \\
\hline
\end{tabular} \\ Li et al.: Melatonin Induces Apoptosis via JNK, P38 and NF-KB}

in HepG2 cells, which was mediated by ER stress and JNK activation [64]. Bcl-2 and Bcl-xL, which are involved in cell apoptosis, also play crucial roles in autophagy [65], and inhibition of Bcl-2 and Bcl-xL expression and enhancement of JNK1/2 signalling may result in the activation of Beclin-1-mediated autophagy [66]. According to these findings and previous reports, we hypothesize that the anticancer effects of melatonin in gastric cancer cells may include cell cycle arrest and autophagy induction via the phosphorylation of MAPK.

Based on previous research, our next step is to study the effects of melatonin combined with chemotherapeutics in gastric cancer cells, possibly providing a reference for physicians to screen for effective chemotherapeutics. Cisplatin is a chemotherapy agent that inhibits cell proliferation and induces apoptosis in various tumour cells. However, the use of cisplatin alone in anti-cancer therapy may not be sufficiently powerful, and its anti-cancer effect may need to be reinforced by adjunct therapy. Melatonin is a widely used antioxidant drug, and its anti-tumour activities have been demonstrated in many studies $[23,67]$. Due to its various functions and low cytotoxicity, melatonin may be used to improve cancer therapeutic efficiency in combination with other chemotherapeutic agents. As demonstrated in our study, we confirmed that melatonin can strengthen cisplatin-mediated antitumour effects in human gastric carcinoma cells by up-regulating the expression of Bax, down-regulating the expression of Bcl-2 and activating the caspase-dependent-apoptotic pathway. In summary, our findings suggest that melatonin may have potential as an anticancer reagent for gastric cancer therapy.

\section{Acknowledgements}

We thank Mrs. Yin Lihui (The First Affiliated Hospital of Wenzhou Medical University, Wenzhou, Zhejiang, China) for providing technical support with cell culture and Miss. Song Xiaoxiao (Department of Otolaryngology, The First Affiliated Hospital of Wenzhou Medical University) for her help with the immunofluorescence assay. This work was supported by a grant from the Science and Technology Bureau of Wenzhou, Zhejiang Province, China (2014S0192).

\section{Disclosure Statement}

The authors declare no conflict of interest.

\section{References}

1 Cui Y, Chen J, He Z, Xiao Y: SUZ12 depletion suppresses the proliferation of gastric cancer cells. Cell Physiol Biochem 2013;31:778-784.

2 Wang J, Sun Y, Bertagnolli MM: Comparison of gastric cancer survival between Caucasian and Asian patients treated in the United States: results from the Surveillance Epidemiology and End Results (SEER) database. Ann Surg Oncol 2015;22:2965-2971.

3 Lissoni P, Brivio F, Ardizzoia A, Tancini G, Barni S: Subcutaneous therapy with low-dose interleukin-2 plus the neurohormone melatonin in metastatic gastric cancer patients with low performance status. Tumori 1993;79:401-404.

4 Slominski RM, Reiter RJ, Schlabritz-Loutsevitch N, Ostrom RS, Slominski AT: Melatonin membrane receptors in peripheral tissues: distribution and functions. Mol Cell Endocrinol 2012;351:152-166.

5 Berra B, Rizzo AM: Melatonin: circadian rhythm regulator, chronobiotic, antioxidant and beyond. Clin Dermatol 2009;27:202-209.

6 Cardinali DP, Esquifino AI, Srinivasan V, Pandi-Perumal SR: Melatonin and the immune system in aging. Neuroimmunomodulation 2007;15:272-278. 


\section{Cellular Physiology Cell Physiol Biochem 2015;37:2323-2338 \begin{tabular}{l|l|l}
\hline DOI: 10.1159/000438587 & $\begin{array}{l}\text { C } 2015 \text { The Author(s). Published by S. Karger AG, Basel } \\
\text { www.karger.com/cpb }\end{array}$ \\
\hline
\end{tabular}

7 Ambriz-Tututi M, Rocha-González HI, Cruz SL, Granados-Soto V: Melatonin: a hormone that modulates pain. Life Sci 2009;84:489-498.

8 Fischer TW, Kleszczyński K, Hardkop LH, Kruse N, Zillikens D: Melatonin enhances antioxidative enzyme gene expression (CAT, GPx, SOD), prevents their UVR-induced depletion, and protects against the formation of DNA damage (8-hydroxy-2'-deoxyguanosine) in ex vivo human skin. J Pineal Res 2013;54:303-312.

9 Das A, McDowell M, Pava MJ, Smith JA, Reiter RJ, Woodward JJ, Varma AK, Ray SK, Banik NL: The inhibition of apoptosis by melatonin in VSC4. 1 motoneurons exposed to oxidative stress, glutamate excitotoxicity, or TNF- $\alpha$ toxicity involves membrane melatonin receptors. J Pineal Res 2010;48:157-169.

10 Espino J, Bejarano I, Ortiz Á, Lozano GM, García JF, Pariente JA, Rodríguez AB: Melatonin as a potential tool against oxidative damage and apoptosis in ejaculated human spermatozoa. Fertil Steril 2010;94:19151917.

11 Espino J, Bejarano I, Redondo PC, Rosado JA, Barriga C, Reiter RJ, Pariente JA, Rodríguez AB: Melatonin reduces apoptosis induced by calcium signaling in human leukocytes: Evidence for the involvement of mitochondria and Bax activation. J Membr Biol 2010;233:105-118.

12 Slominski AT, Kleszczyński K, Semak I, Janjetovic Z, Żmijewski MA, Kim T-K, Slominski RM, Reiter RJ, Fischer TW: Local melatoninergic system as the protector of skin integrity. Int J Mol Sci 2014;15:1770517732.

13 Martín-Renedo J, Mauriz JL, Jorquera F, Ruiz-Andrés O, González P, González-Gallego J: Melatonin induces cell cycle arrest and apoptosis in hepatocarcinoma HepG2 cell line. J Pineal Res 2008;45:532-540.

14 Cucina A, Proietti S, D’Anselmi F, Coluccia P, Dinicola S, Frati L, Bizzarri M: Evidence for a biphasic apoptotic pathway induced by melatonin in MCF-7 breast cancer cells. J Pineal Res 2009;46:172-180.

15 Zhou Q Gui S, Zhou Q, Wang Y: Melatonin inhibits the migration of human lung adenocarcinoma A549 cell lines involving JNK/MAPK pathway. PLoS One 2014;9:e101132.

16 Xu L, Liu H, Zhang H, Wang RX, Song J, Zhou RX: Growth-Inhibitory Activity of Melatonin on Murine Foregastric Carcinoma Cells In Vitro and the Underlying Molecular Mechanism. Anat Rec 2013;296:914920.

17 Xu L, Jin QD, Gong X, Liu H, Zhou RX: Anti-gastric cancer effect of melatonin and Bcl-2, Bax, p21 and p53 expression changes. Sheng Li Xue Bao 2014;66:723-729.

18 Ordoñez R, Carbajo-Pescador S, Prieto-Dominguez N, García-Palomo A, González-Gallego J, Mauriz JL: Inhibition of matrix metalloproteinase- 9 and nuclear factor kappa $B$ contribute to melatonin prevention of motility and invasiveness in HepG2 liver cancer cells. J Pineal Res 2014;56:20-30.

19 Zhang S, Qi Y, Zhang H, He W, Zhou Q, Gui S, Wang Y: Melatonin inhibits cell growth and migration, but promotes apoptosis in gastric cancer cell line, SGC7901. Biotech Histochem 2013;88:281-289.

20 Chang L, Karin M: Mammalian MAP kinase signalling cascades. Nature 2001;410:37-40.

21 Yang R, Piperdi S, Gorlick R: Activation of the RAF/mitogen-activated protein/extracellular signalregulated kinase kinase/extracellular signal-regulated kinase pathway mediates apoptosis induced by chelerythrine in osteosarcoma. Clin Cancer Res 2008;14:6396-6404.

22 Hsieh MH, Nguyen HT: Molecular mechanism of apoptosis induced by mechanical forces. Int Rev Cytol 2005;245:45-90.

23 Joo SS, Yoo YM: Melatonin induces apoptotic death in LNCaP cells via p38 and JNK pathways: therapeutic implications for prostate cancer. J Pineal Res 2009;47:8-14.

24 Tan J, Wang Y, Xia Y, Zhang N, Sun X, Yu T, Lin L: Melatonin protects the esophageal epithelial barrier by suppressing the transcription, expression and activity of myosin light chain kinase through ERK1/2 signal transduction. Cell Physiol Biochem 2014;34:2117-2127.

25 Crawford LJ, Walker B, Irvine AE: Proteasome inhibitors in cancer therapy. J Cell Commun Signal 2011;5:101-110.

26 Tamura EK, Cecon E, Monteiro AWA, Silva CLM, Markus RP: Melatonin inhibits LPS-induced NO production in rat endothelial cells. J Pineal Res 2009;46:268-274.

27 Gilad E, Wong HR, Zingarelli B, Virág L, O'Connor M, Salzman AL, Szabó C: Melatonin inhibits expression of the inducible isoform of nitric oxide synthase in murine macrophages: role of inhibition of NFKB activation. FASEB J 1998;12:685-693.

28 Galvao J, Davis B, Tilley M, Normando E, Duchen MR, Cordeiro MF: Unexpected low-dose toxicity of the universal solvent DMSO. FASEB J 2014;28:1317-1330. 


\section{Cellular Physiology Cell Physiol Biochem 2015;37:2323-2338

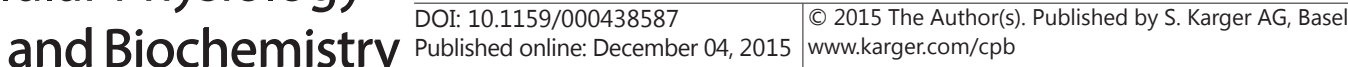 \\ Li et al.: Melatonin Induces Apoptosis via JNK, P38 and NF-KB}

29 Wang Y, Gao S, Liu G, Jia R, Fan D, Feng X: Microarray expression profile analysis of long non-coding RNAs in human gastric cardiac adenocarcinoma. Cell Physiol Biochem 2014;33:1225-1238.

30 Park SB, Goldstein D, Krishnan AV, Lin CSY, Friedlander ML, Cassidy J, Koltzenburg M, Kiernan MC: Chemotherapy-induced peripheral neurotoxicity: A critical analysis. CA Cancer J Clin 2013;63:419-437.

31 Baxter SD, Teft WA, Choi Y-H, Winquist E, Kim RB: Tamoxifen-associated hot flash severity is inversely correlated with endoxifen concentration and CYP3A4*22. Breast Cancer Res Treat 2014;145:419-428.

32 Saleh-Ebrahimi L, Zwicker F, Muenter MW, Bischof M, Lindel K, Debus J, Huber PE, Roeder F: Intensity modulated radiotherapy (IMRT) combined with concurrent but not adjuvant chemotherapy in primary nasopharyngeal cancer-a retrospective single center analysis. Radiat Oncol 2013;8:20.

33 Hsiang C-H, Tunoda T, Whang YE, Tyson DR, Ornstein DK: The impact of altered annexin I protein levels on apoptosis and signal transduction pathways in prostate cancer cells. Prostate 2006;66:1413.

34 Mukherjee JJ, Gupta SK, Kumar S: Inhibition of benzopyrene-diol-epoxide (BPDE)-induced bax and caspase- 9 by cadmium: Role of mitogen activated protein kinase. Mutat Res 2009;661:41-46.

35 Sainz RM, Reiter RJ, Tan DX, Roldan F, Natarajan M, Quiros I, Hevia D, Rodriguez C, Mayo JC: Critical role of glutathione in melatonin enhancement of tumor necrosis factor and ionizing radiation-induced apoptosis in prostate cancer cells in vitro. J Pineal Res 2008;45:258-270.

36 Wang X, Martindale JL, Holbrook NJ: Requirement for ERK activation in cisplatin-induced apoptosis. J Biol Chem 2000;275:39435-39443.

37 Huang HL, Hsieh MJ, Chien MH, Chen HY, Yang SF, Hsiao PC: Glabridin mediate caspases activation and induces apoptosis through JNK1/2 and p38 MAPK pathway in human promyelocytic leukemia cells. PLoS One 2014;9:e98943.

38 Zhou Y, Zhao W, Xie G, Huang M, Hu M, Jiang X, Zeng D, Liu J, Zhou H, Chen H, Wang GH, Zhang XK: Induction of Nur77-dependent apoptotic pathway by a coumarin derivative through activation of JNK and p38 MAPK. Carcinogenesis 2014;35:2660-2669.

39 Liu J, Wu N, Ma L-N, Zhong J-T, Liu G, Zheng L-H, Lin X-K: p38 MAPK Signaling Mediates Mitochondrial Apoptosis in Cancer Cells Induced by Oleanolic Acid. Asian Pac J Cancer Prev 2013;15:4519-4525.

40 Aggarwal BB: Nuclear factor- $\kappa B$ : the enemy within. Cancer cell 2004;6:203-208.

41 Deorukhkar A, Krishnan S, Sethi G, Aggarwal BB: Back to basics: how natural products can provide the basis for new therapeutics. Expert Opin Investig Drugs 2007;16:1753-1773.

42 Ahn KS, AGGARWAL BB: Transcription Factor NF-кB: A Sensor for Smoke and Stress Signals. Ann N Y Acad Sci 2005; 1056:218-233.

43 Yuan L, Wei S, Wang J, Liu X: Isoorientin induces apoptosis and autophagy simultaneously by reactive oxygen species (ROS)-related p53, PI3K/Akt, JNK, and p38 signaling pathways in HepG2 cancer cells. J Agric Food Chem 2014;62:5390-5400.

44 Bharti AC, Donato N, Singh S, Aggarwal BB: Curcumin (diferuloylmethane) down-regulates the constitutive activation of nuclear factor $-\kappa B$ and I $\mathrm{B} \boldsymbol{\alpha} \alpha$ kinase in human multiple myeloma cells, leading to suppression of proliferation and induction of apoptosis. Blood 2003;101:1053-1062.

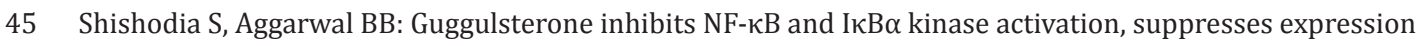
of anti-apoptotic gene products, and enhances apoptosis. J Biol Chem 2004;279:47148-47158.

46 Takada Y, Aggarwal BB: Flavopiridol inhibits NF-kappaB activation induced by various carcinogens and inflammatory agents through inhibition of IkappaBalpha kinase and p65 phosphorylation: abrogation of cyclin D1, cyclooxygenase-2, and matrix metalloprotease-9. J Biol Chem 2004;279:4750-4759.

47 Yang X-S, Liu S-A, Liu J-W, Yan Q: Fucosyltransferase IV Enhances Expression of MMP-12 Stimulated by EGF

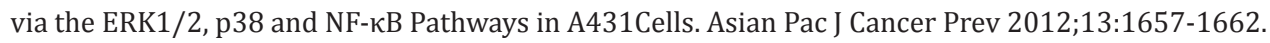

48 Kook S-H, Jang Y-S, Lee J-C: Involvement of JNK-AP-1 and ERK-NF- $\kappa B$ signaling in tension-stimulated expression of type I collagen and MMP-1 in human periodontal ligament fibroblasts. J Appl Physiol 2011;111:1575-1583.

49 Lee S-J, Cho S-C, Lee E-J, Kim S, Lee S-B, Lim J-H, Choi YH, Kim W-J, Moon S-K: Interleukin-20 promotes migration of bladder cancer cells through extracellular signal-regulated kinase (ERK)-mediated MMP-9 protein expression leading to nuclear factor (NF- $\kappa \mathrm{B}$ ) activation by inducing the up-regulation of p21WAF1 protein expression. J Biol Chem 2013;288:5539-5552.

50 Yeh M-H, Kao S-T, Hung C-M, Liu C-J, Lee K-H, Yeh C-C: Hesperidin inhibited acetaldehyde-induced matrix metalloproteinase-9 gene expression in human hepatocellular carcinoma cells. Toxicol Lett 2009;184:204210. 


\section{Cellular Physiology Cell Physiol Biochem 2015;37:2323-2338

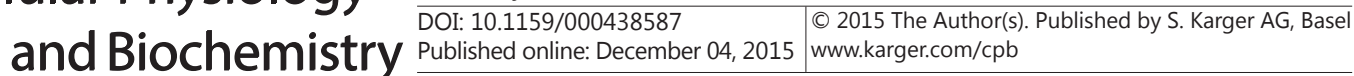 \\ Li et al.: Melatonin Induces Apoptosis via JNK, P38 and NF-KB}

51 Kim KJ, Cho KD, Jang KY, Kim HA, Kim HK, Lee HK, Im SY: Platelet-activating factor enhances tumour metastasis via the reactive oxygen species-dependent protein kinase casein kinase 2-mediated nuclear factor- $\mathrm{\kappa B}$ activation. Immunology 2014;143:21-32.

52 Hsieh H-L, Wang H-H, Wu W-B, Chu P-J, Yang C-M: Transforming growth factor-b1 induces matrix metalloproteinase- 9 and cell migration in astrocytes: roles of ROS-dependent ERK-and JNK-NF- $\mathrm{KB}$ pathways. J Neuroinflammation 2010;7:88.

53 Yi J, Yang X, Zheng L, Yang G, Sun L, Bao Y, Wu Y, Huang Y, Yu C, Yang S-N: Photoactivation of hypericin decreases the viability of RINm5F insulinoma cells through reduction in JNK/ERK phosphorylation and elevation of caspase-9/caspase-3 cleavage and Bax-to-Bcl-2 ratio. Biosci Rep 2015;35:1-13.

54 Meng G, Wang W, Chai K, Yang S, Li F, Jiang K: Combination treatment with triptolide and hydroxycamptothecin synergistically enhances apoptosis in A549 lung adenocarcinoma cells through PP2A-regulated ERK, p38 MAPKs and Akt signaling pathways. Int J Oncol 2015;46:1007-1017.

55 Liu QQ, Zhang FF, Wang F, Qiu JH, Luo CH, Zhu GY, Liu YF: TIPE2 Inhibits Lung Cancer Growth Attributing to Promotion of Apoptosis by Regulating Some Apoptotic Molecules Expression. PLoS One 2015;10:e0126176.

56 Swanson RA, Ying W, Kauppinen TM: Astrocyte influences on ischemic neuronal death. Curr Mol Med 2004;4:193-205.

57 Wei P, Cui G, Lu Q, Yang L, Guan Z, Sun W, Zhao Y, Wang S, Peng Q: A20 promotes Brucella intracellular growth via inhibition of macrophage cell death and activation. Vet Microbiol 2015;175:50-57.

58 Wang H-Q, Li D-L, Lu Y-J, Cui X-X, Zhou X-F, Lin W-P, Conney AH, Zhang K, Du Z-Y, Zheng X: Anticancer Activity of Acanthopanax trifoliatus (L) Merr Extracts is Associated with Inhibition of NF- $\kappa$ B Activity and Decreased Erk1/2 and Akt Phosphorylation. Asian Pac J Cancer Prev 2013;15:9341-9346.

59 Matteucci C, Minutolo A, Marino-Merlo F, Grelli S, Frezza C, Mastino A, Macchi B: Characterization of the enhanced apoptotic response to azidothymidine by pharmacological inhibition of NF- $\kappa$ B. Life Sci 2015;127:90-97.

60 Collett GP, Campbell FC: Curcumin induces c-jun N-terminal kinase-dependent apoptosis in HCT116 human colon cancer cells. Carcinogenesis 2004;25:2183-2189.

61 Chen YN, Cheng CC, Chen JC, Tsauer W, Hsu SL: Norcantharidin-induced apoptosis is via the extracellular signal-regulated kinase and c-Jun-NH2-terminal kinase signaling pathways in human hepatoma HepG2 cells. Br J Pharmacol 2003;140:461-470.

62 Bain J, Plater L, Elliott M, Shpiro N, Hastie C, Mclauchlan H, Klevernic I, Arthur J, Alessi D, Cohen P: The selectivity of protein kinase inhibitors: a further update. Biochem. J 2007;408:297-315.

63 Bacus SS, Gudkov AV, Lowe M, Lyass L, Yung Y, Komarov AP, Keyomarsi K, Yarden Y, Seger R: Taxol-induced apoptosis depends on MAP kinase pathways (ERK and p38) and is independent of p53. Oncogene 2001;20:147-155.

64 Ordonez R, Fernandez A, Prieto-Dominguez N, Martinez L, Garcia-Ruiz C, Fernandez-Checa JC, Mauriz JL, Gonzalez-Gallego J: Ceramide metabolism regulates autophagy and apoptotic cell death induced by melatonin in liver cancer cells. J Pineal Res 2015;59:178-189.

65 Zhou F, Yang Y, Xing D: Bcl-2 and Bcl-xL play important roles in the crosstalk between autophagy and apoptosis. FEBS J 2011;278:403-413.

66 Hsieh MJ, Lin CW, Chiou HL, Yang SF, Chen MK: Dehydroandrographolide, an iNOS inhibitor, extracted from Andrographis paniculata (Burm.f.) Nees, induces autophagy in human oral cancer cells. Oncotarget 2015;6:30831-30849.

67 Rondanelli M, Faliva MA, Perna S, Antoniello N: Update on the role of melatonin in the prevention of cancer tumorigenesis and in the management of cancer correlates, such as sleep-wake and mood disturbances: review and remarks. Aging Clin Exp Res 2013;25:499-510. 